\title{
Prevalence of Substance Use in Patients Diagnosed with Schizophrenia
}

\author{
Yasemin TEKIN ULUDAĞ', Gülcan GÜLEÇ² \\ 'Clinic of Psychiatry, Eskişehir State Hospital, Eskişehir, Turkey \\ ${ }^{2}$ Department of Psychiatry, Eskişehir Osmangazi University School of Medicine, Eskişehir, Turkey
}

\section{ABSTRACT}

Introduction: Substance abuse among schizophrenic patients is a growing clinical concern. Substance use disorders and their effects on the course of schizophrenia have made the identification and treatment of schizophrenic patients a high priority. This study aimed to investigate the prevalence of substance use, preferred types of substances, sociodemographic characteristics and clinical features of schizophrenia, and substance use impact in schizophrenic patients.

Methods: Hundred patients who were consecutively admitted to the psychiatry clinic and were diagnosed with schizophrenia according to the DSM-IV criteria were enrolled in this study. Individual interviews were conducted during the patients. In order to evaluate substance abuse disorder (SAD) as per DSM-IV criteria, the substance use disorder section of the structured clinical interview for DSM disorders-II (SCID-II) form was used. In addition, the following were applied to schizophren-ic patients: sociodemographic data form, medical history form, Brief Disability Questionnaire (BDQ), UKU Side Effect Rating Scale (UKUSERS), Insight Rating Scale (IRS), Alcohol Use Dis-orders Identification Test (AUDIT), Fagerstrom Nicotine Dependence Test (FNDT), Global As-sessment of Functioning Scale (GAF), Scale for the Assessment of Positive Symptoms (SAPS), Scale for the Assessment of Negative Symptoms (SANS), and Calgary Depression Scale (CDS).
Results: Schizophrenia and alcohol and drug use were more common in males, and youn 7 ger age was found to have no association with substance use. Unemployment, low education levels, rural survival rates, age at disease onset, the doctor first age of the applicant, the first inpati-nent years, legal issues, harm caused by others and suicidal behavior, SAPS, SANS, CDS received from their scores significant difference was detected. Schizophrenic patients with substance use had higher side effects of drugs, disability, and psychopathology sco $\neg$ res than schizophrenic patients without substance use. The functioning of schizophrenic pati-nents with substance use was worse, and the total length of stay was longer. Nicotine, alcohol, biperiden, cannabis, and volatile substances were the preferred materials most commonly used by schizophrenic patients.

Conclusion: In our country, limited research has been conducted on the prevalence of substance use in schizophrenic patients. Therefore, we believe that this study will contribute to the literature on the subject. More sample groups and first-episode patients as well as follow-up studies will contribute to a better understanding of the effect of substance use on the clinical course of schizophrenia.

Keywords: schizophrenia, alcohol-related disorders, substance-related disorders, behavior, addictive, prevalence

\section{INTRODUCTION}

The main reason underlying the recent increased interest shown toward the association of schizophrenia and substance abuse is the realization of the significant contribution of comorbidities on diagnosis, treatment, and prognosis (I). In clinical samples and epidemiological research, increased rates of the comorbidity of substance abuse accompanied with the primary diagnosis of schizophrenia have been observed $(2,3)$. Substance abuse disorder (SAD) is reported to be the most frequent comorbidity in patients evaluated during their first psychotic episode $(4,5)$. After reviewing recent studies, evidence indicates that the rate of lifelong substance abuse in schizophrenic patients ranges between $40 \%$ and $70 \%(6,7)$. These figures vary according to the samples studied, socio-demographical characteristics, presence of substance abuse and substance addiction, and the specific type of substance abuse evaluated. For cases in which only the general prevalence of substance abuse was studied, the aforementioned figures varied according to the current or lifelong diagnosis and depending on whether cigarettes, alcohol, or other illegal substances were used (8).

Additional diagnosis of substance use disorder (SUD) can affect the natural history of disease, disease recurrence, patient quality of life, and treatment compliance in patients with schizophrenia (9). Among schizophrenic patients with SUD, there are increased rates of hospital admissions, more severe disease progression (10), more serious hallucinations and delusions, and more frequent positive symptoms in alcohol-addicted patients than non-alcohol-addicted patients as well as more negative symptoms in schizophrenic patients who are smokers than those who are non-smokers $(I 0, I \mathrm{I})$. Studies have also shown that SUD in schizophrenic patients is closely related to increased rates of criminal activity, violent behavior, and involvement in the legal system (I2). 
The number of studies conducted in Turkey on the prevalence of smoking and alcohol and drug use among schizophrenic patients is limited. Therefore, in this study, we aimed to investigate the prevalence of substance use in patients presenting to the Psychiatry Outpatient Clinics of the Eskişehir Osmangazi University School of Medicine who were diagnosed with schizophrenia; we also investigated the effect of substance use on disease progression.

\section{METHODS}

\section{Sample}

The study included 85 consecutive patients admitted to the Psychiatry Outpatient Clinics of Eskişehir Osmangazi University School of Medicine and 15 patients concurrently presenting to the Eskişehir Public Mental Health Centre with a diagnosis of schizophrenia, as defined according to the DSM-IV diagnostic criteria. The inclusion criteria used for the study included being in a state of remission and having no underlying neurological disorder, no mental retardation, and no history of head trauma or organic brain syndromes. The study was approved by the local ethics committee of the Eskişehir Osmangazi University School of Medicine on December 23, 2011 with a serial number of 335.

\section{Materials Used}

Structured Clinical Interview for DSM-IV Axis-I Disorders (SCID-I): Developed by First et al. (13) to investigate axis-I mental illnesses according to DSM-IV. The Turkish version of this exam was validated (14).

Socio-demographical Data and Disease History Form: Developed by investigators to evaluate the social and demographical characteristics of patients and the history of their diseases.

Brief Disability Questionnaire (BDQ): Developed by the World Health Organisation to evaluate loss of physical and social capabilities. This index was translated into Turkish and was validated (I5).

UKU Side Effect Rating Scale (UKUSERS): Developed by Lingjaerde et al. (16) to evaluate the clinical side effects due to the use of psychotropic agents at therapeutic dosages.

Alcohol Use Disorders Identification Test (AUDIT): Developed by the World Health Organisation to determine the harmful and risky consumption levels of alcohol (17). The validity and reliability analysis of the Turkish version of this form was performed by Saatcioglu et al. ( 18).

Fagerström Nicotine Dependence Test (FNDT): Developed by Fagerström et al. (19) to evaluate nicotine addiction. This test is used to determine the amount of cigarette consumption of an individual and the grade of his/her ability to cope without smoking. The grade of nicotine addiction is denominated as very low, low, mild, high, and very high. The Turkish version of this test was validated (20).

Insight Rating Scale (IRS): Developed by David (2I), the scale consists of 4 sections that aim to evaluate the acceptance of disease, designation of the psychotic experiences as abnormal, compliance with treatment, and awareness of any past psychological disorders. The Turkish version was validated (22).

Global Assessment of Functioning scale (GAF): This scale, used in DSM-IV axis $\mathrm{V}$, is a tool for evaluating an individual's psychological, social, and occupational functionality, excluding disturbances caused by physical or environmental factors $(23,24)$.

Scale for the Assessment of Positive Symptoms (SAPS): Developed by Anderasen (25), this test is used to evaluate the level of positive signs, distribution, and change in the severity of schizophrenia. It contains 4 domains consisting of hallucination, delusion, strange behavior, and positive formal thinking disorder, with 34 symptoms arranged under the different domains. The Turkish version was validated by Erkoç et al. (26).

Scale for the Assessment of Negative Symptoms (SANS): Developed by Anderasen (27), this test consists of 5 domains: flattening of effect, alogia, avulsion, anhedonia, and attention deficit, with 25 symptoms arranged under the different domains. The Turkish version was validated by Erkoç et al. (28).

Calgary Depression Scale (CDS): Developed by Addington et al. (29) to evaluate depression and the level and severity of the symptoms of depression in patients with schizophrenia. Consistency and reliability analysis was performed by Aydemir et al. (30), and the cut-off point for the scale in the study of sensitivity and specificity analysis in the Turkish study was set as $11 / 12$.

\section{Application}

Prior to conducting the study, patients were informed about the study's aim, definition, and details and were informed that they could withdraw from being interviewed at any time or refrain from participating in the study. All patients agreed to participate in the study. One-on-one interviews were conducted with patients, and their diagnoses were confirmed by the Structured Clinical Interview for DSM-IV Axis-I Disorders (SCID-I). To evaluate SUD, the SUD section of the SCID-I form, structured according to the DSM-IV, was used. The interviewer applied all the scales and tests to the patients in a single session. It took an average of 60-90 min to complete the evaluation and tests. In each of the patients, including those with alcohol-SUD according to the DSM-IV diagnostic criteria, their history or current use of alcohol, nicotine, or other substance(s) was determined. The patients were divided into 2 groups, namely, alcohol substance users and non-users, and the groups were compared in terms of socio-demographic features, disease characteristics, and the results obtained from the tests and scales. The group designated lifelong nicotine-alcohol-substance use (LLNAS) consisted of patients with a lifelong history of alcohol substance use plus patients who engaged in nicotine use; analyses were performed on LLNAS users and non-users. Analyses were also repeated for patients who met and those who did not meet the requirements of the lifelong alcohol substance abuse and addiction criteria (LLASUD).

\section{Statistical Analyses}

All data analyses were performed using the SPSS I 5 package programme. Upon conducting the Kolmogorov-Smirnov analysis of the data, it was determined that none of the variables were normally distributed. Therefore, numerical variables were analyzed using the Mann-Whitney $U$ test, and categorical variables were analyzed using the chi-square test. A p value of $<0.05$ was considered to be statistically significant.

\section{RESULTS}

\section{General Characteristics of Schizophrenia Sample Group}

The median age of the schizophrenia patient group was 42 (32-5I) years. Thirty-three percent of the patients were female $(n=33)$, and $67 \%$ were male. The median years of education was II (5- II); $41 \%(n=4 I)$ of patients were married and $45 \%(n=45)$ were not. The median age at which 5 
the symptoms started was 20 (18-28) years, and the median duration of the disease was 15 (8-26) years. The socio-demographic and clinical characteristics of the sample group are shown in Table 1.

Seventy percent $(n=70)$ of the 100 schizophrenic patients included in the study had smoked at some point in their lifetime. Eighteen percent $(n=18)$ had stopped smoking, while 52\% $(n=52)$ had continued smoking. The prevalence of alcohol consumption in schizophrenic patients was 32\% $(n=32)$. Twenty-four percent of the patients were social smokers, and the number of patients who were found to have alcohol abuse or addiction (alcohol consumption disorder) was 8 (8\%). Lifelong prevalence of substance use in schizophrenic patients was 14\%. Multiple substance use was detected in 6 (6\%) schizophrenic patients who used substances. When we observed those who continued alcohol substance use, 18\% $(n=18)$ were current alcohol users and $2 \%(n=2)$ had alcohol use disorder. Current SUD was observed in 3 (3\%) of the patients (Table 2).

\section{Comparison of Lifelong Substance Use Schizophrenic Pa- tients and Patients without Lifelong Alcohol Substance Use}

Excluding nicotine users, when comparing the socio-demographical characteristics of schizophrenic patients who are alcohol substance users $(n=4 I)$ with those who are not $(n=59)$, there was no significant difference in terms of gender distribution. In the alcohol substance user schizophrenia (A-S+ Schizophrenia) group, a higher proportion $(p=0.00 \mathrm{I}$ ) of patients was male. There was a statistically significant difference in work status between the two groups. The percentage of unemployed patients was higher in the alcohol substance non-user schizophrenia group (A-S - Schizophrenia), whereas the percentage of systematic employment and being retired was higher in the A-M+ Schizophrenia group $(p=0.0 \mathrm{I} I)$. Other than gender and employment status, there was no statistically significant difference between the two groups in terms of birth place, place of settlement, marital status, duration of education, number of marriages, number of children, number of siblings, monthly income, and welfare support, i.e., in cases when the support receieved constituted the majority of the person's income ( $p>0.05)$.

When the A-M+ Schizophrenia and A-M- Schizophrenia groups were compared in terms of disease history, it was observed that the total hospital stay $(p=0.021)$ and lifelong nicotine use $(p=0.00 \mathrm{I})$ were higher in the $\mathrm{A}-\mathrm{M}+$ Schizophrenia group than in the A-M- Schizophrenia group. There was no statistically significant difference between the two groups in terms of the age at the onset of disease symptoms, age at first hospital admission, age at first hospital stay, duration of diseased years, number of suicides, total number of ECT sessions during hospital stay, history of legal conflicts, method of crime, history of penal custody, history of imprisonment, history of legal conflicts in the family, suicide attempts, acts of selfharm, and current nicotine use. When the total scores obtained from the applied tests and scales were compared between the A-M+ Schizophrenia and A-M- Schizophrenia groups, there was no statistically significant difference $(p>0.05)$. The statistically significant differences between the two groups in terms of socio-demographical features, disease history, and the scores of the applied scales are shown in Table 3.

\section{Comparison of Lifelong Nicotine, Alcohol, and Substance User Schizophrenic Patients and Non-Users}

When repeating our analyses after including nicotine users among the lifelong alcohol substance users, the LLNAS use rates were $75 \%(n=75)$ in the schizophrenia group. Among these 75 patients, 17 (23\%) were females and 58 (77\%) were males. The LLNAS non-user schizophrenia patient group constituted 25 patients, out of which 16 (64\%) females and 9 (36\%) males. When we compared the socio-demographical characteristics in the 6 schizophrenia group of LLNAS users and non-users, we observed high- er proportions of males $(p<0.000)$, retired or regular-non interrupted workers $(p=0.003)$, longer hospital stays $(p=0.004)$, younger ages at first hospitalization $(p=0.04 \mathrm{I})$, and higher incidences of self-harming behavior $(p=0.038)$ among the LLNAS user group than the non-user group. There were no other significant differences between groups in terms of oth-

Table I. Socio-demographical and medical history characteristics of the schizophrenia sample group

\begin{tabular}{|c|c|c|c|}
\hline \multicolumn{2}{|l|}{ Sample group $(n=100)$} & \multicolumn{2}{|c|}{ Median (25-75\%) } \\
\hline \multicolumn{2}{|l|}{ Age } & \multicolumn{2}{|c|}{$42(32-51)$} \\
\hline \multicolumn{2}{|c|}{ Duration of Education (years) } & \multicolumn{2}{|c|}{||$(5-||)$} \\
\hline \multicolumn{2}{|l|}{ Monthly income (TL) } & \multicolumn{2}{|c|}{$1000(700-1300)$} \\
\hline \multicolumn{2}{|l|}{ Age at disease onset } & \multicolumn{2}{|c|}{$20(18-28)$} \\
\hline \multicolumn{2}{|c|}{ Age at the beginning of the treatment } & \multicolumn{2}{|c|}{$24(19-30)$} \\
\hline \multicolumn{4}{|c|}{ Age at first hospitalization 24 (19-33) } \\
\hline \multicolumn{2}{|c|}{ Duration of diseased years (in years) } & \multicolumn{2}{|c|}{$15(8-26)$} \\
\hline \multicolumn{2}{|c|}{ Total hospital stay (in months) } & \multicolumn{2}{|c|}{$3(2-6)$} \\
\hline & & $\mathbf{n}$ & $\%$ \\
\hline \multirow[t]{2}{*}{ Gender } & Female & 33 & 33 \\
\hline & Male & 67 & 67 \\
\hline \multirow[t]{2}{*}{ Place of birth } & Village-town & 60 & 60 \\
\hline & City & 40 & 40 \\
\hline \multirow[t]{2}{*}{ Place of living } & Village-town & 85 & 85 \\
\hline & City & 15 & 15 \\
\hline \multirow[t]{3}{*}{ Marital status } & Married & 41 & 41 \\
\hline & Unmarried & 45 & 45 \\
\hline & Widow-divorced & 14 & 14 \\
\hline \multirow[t]{4}{*}{ Employment status } & Unemployed & 38 & 38 \\
\hline & Retired & 32 & 32 \\
\hline & Irregular worker & 12 & 12 \\
\hline & Regular worker & 18 & 18 \\
\hline \multirow[t]{2}{*}{ Legal conflict } & Yes & 8 & 8 \\
\hline & No & 92 & 92 \\
\hline \multirow[t]{2}{*}{ History of penal custody } & Yes & 7 & 7 \\
\hline & No & 93 & 93 \\
\hline \multirow[t]{2}{*}{ Prison stay } & Yes & 2 & 2 \\
\hline & No & 98 & 98 \\
\hline \multirow[t]{2}{*}{ Suicide attempt } & Yes & 35 & 35 \\
\hline & No & 65 & 65 \\
\hline Self-harm & Yes & 18 & 18 \\
\hline & No & 82 & 82 \\
\hline Homicide attempt & Yes & 10 & 10 \\
\hline & No & 90 & 90 \\
\hline Psychiatric disease in first & degree relatives & & \\
\hline & No & 50 & 50 \\
\hline & Schizophrenia & 32 & 32 \\
\hline & Affect disorders & 10 & 10 \\
\hline & Anxiety disorders & 5 & 5 \\
\hline & Alcohol substance & 2 & 2 \\
\hline & Others & I & I \\
\hline
\end{tabular}


Table 2. Distribution of nicotine, alcohol, and substance use in schizophrenic patients

\begin{tabular}{|l|c|c|}
\hline & n & $\%$ \\
\hline Lifelong cigarette smoking & 70 & 70 \\
\hline Current cigarette smoking & 52 & 2 \\
\hline Lifelong alcohol use & 32 & 32 \\
\hline Lifelong alcohol use disorder (AUD) & 8 & 8 \\
\hline Lifelong substance use & 14 & 14 \\
\hline Biperiden & 9 & 9 \\
\hline Marijuana & 4 & 4 \\
\hline Volatile substance & 3 & 3 \\
\hline Benzodiazepine & 1 & 1 \\
\hline Amphetamine & 1 & 1 \\
\hline Current alcohol use & 18 & 18 \\
\hline Current alcohol use disorder & 2 & 2 \\
\hline Current biperiden use disorder & 3 & 3 \\
\hline
\end{tabular}

er features of the disease history ( $p>0.05)$. Furthermore, the UKUSERS autonomic sub-scale score was found to be higher in the LLNAS user group than in the non-user group $(p=0.04)$. In the other tests and scales, no significant difference between groups was evident $(p>0.05)$. When comparing the socio-demographical characteristics, disease history, and total scores obtained from the tests, there were no statistically significant differences between the LLNAS user and non-user schizophrenia groups. The significantly different variables are shown in Table 4.

\section{Comparison of Schizophrenia Patient Groups with and with- out LLASUD}

In the schizophrenia patient group included in the study, LLASUD was found to be 19\%. The same statistical analyses were also applied to schizophrenic patients with and without LLASUD. Imprisonment was seen more frequently in patients with LLASUD ( $p=0.035)$. Lastly, the schizophrenia group with LLASUD had obtained lower scores on the GAF scale than that without LLASUD $(p=0.035)$.

\section{DISCUSSION}

For years, the relationship between schizophrenia and smoking has attracted attention. Various studies have reported the prevalence of smok-

Table 3. Comparison of alcohol substance user and non-user schizophrenic patients

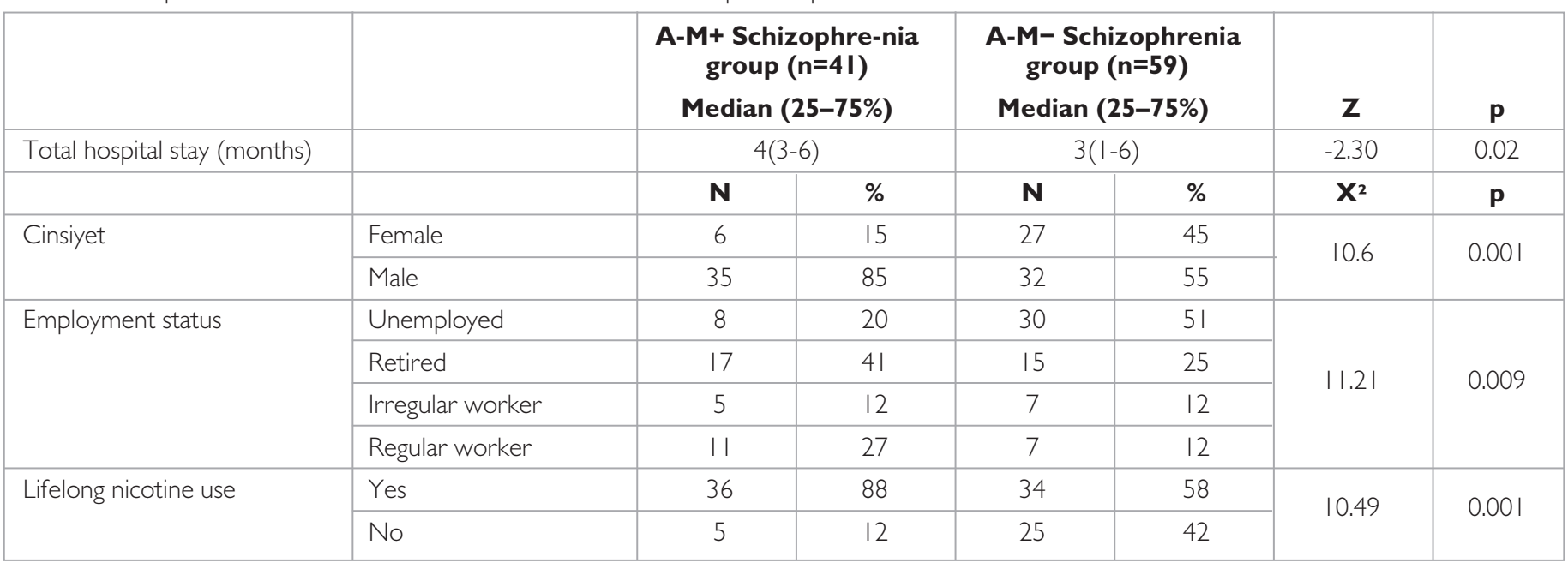

Table 4. Comparison of LLNAS user and non-user schizophrenia groups

\begin{tabular}{|c|c|c|c|c|c|c|c|}
\hline & & \multicolumn{2}{|c|}{$\begin{array}{l}\text { LLNAS user schizophrenia } \\
\text { group }(n=75) \\
\text { Median }(25-75 \%)\end{array}$} & \multicolumn{2}{|c|}{$\begin{array}{l}\text { YBNAM kullanmayan } \\
\text { schizophrenia group }(n=25) \\
\text { Median }(25-75 \%)\end{array}$} & $\mathbf{Z}$ & $\mathbf{p}$ \\
\hline Age at first hospitalization & & \multicolumn{2}{|c|}{$20(16.5-25)$} & \multicolumn{2}{|c|}{$27.4(17-29.4)$} & -2.843 & $<0.01$ \\
\hline Total duration of hospitalization & & \multicolumn{2}{|c|}{$4(2.75-6)$} & \multicolumn{2}{|c|}{$3.1(2.4-5.6)$} & -2.045 & $<0.05$ \\
\hline \multirow[t]{2}{*}{ UKUSERS autonomic } & & \multicolumn{2}{|c|}{$2(1-4)$} & \multicolumn{2}{|c|}{$1.5(1-3)$} & -2.032 & $<0.05$ \\
\hline & & $\mathbf{n}$ & $\%$ & $\mathbf{n}$ & $\%$ & $\mathbf{X}^{2}$ & $\mathbf{p}$ \\
\hline \multirow[t]{2}{*}{ Gender } & Female & 17 & 23 & 16 & 64 & \multirow{2}{*}{14.488} & \multirow{2}{*}{$<0.001$} \\
\hline & Male & 58 & 77 & 9 & 36 & & \\
\hline \multirow[t]{4}{*}{ Employment status } & Unemployed & 21 & 28 & 17 & 68 & \multirow{4}{*}{$|3.6|$} & \multirow{4}{*}{$<0.01$} \\
\hline & Retired & 28 & 37 & 4 & 16 & & \\
\hline & Irregular-interrupted & 9 & 12 & 3 & 12 & & \\
\hline & Regular-uninterrupted & 17 & 23 & 1 & 4 & & \\
\hline \multirow[t]{2}{*}{ Self-harm } & Yes & 17 & 23 & 1 & 4 & \multirow{2}{*}{4.43} & \multirow{2}{*}{$<0.05$} \\
\hline & No & 58 & 77 & 24 & 96 & & \\
\hline
\end{tabular}


ing in schizophrenic patients to be between 56-88\% (31,32,33). In Turkey, the rate of smoking in schizophrenic patients was reported to be between $50-76 \%(34,35,36,37,38)$. In the present patients, 70 of the 100 schizophrenic patients (70\%) were lifelong smokers. The rate of nicotine use in schizophrenic patients in our study was found to be similar to that reported in other studies conducted in Turkey.

In an epidemiological field study performed by the American National Mental Health Institute (8), $47 \%$ of the individuals with schizophrenia spectrum disorder were found to meet the criteria of alcohol SUD and other measures. This rate was found to be $33.7 \%$ for alcohol use disorder and $27.5 \%$ for SUD. Moreover, results revealed that alcohol SUD, alcohol use disorder, and the use disorder of substances other than alcohol were $4.6,3$, and 9 times, respectively, more frequent in individuals with schizophrenia than in the general population (8). These rates are far higher than the rate reported for alcohol SUD in our study. In addition, in Turkey, alcohol substance use rates are significantly lower than those in the general population (39). On evaluating the results of 32 studies, Mueser et al. (5) found that the diagnosis of alcohol consumption disorder in schizophrenic patients ranged between $12.3-50 \%$, whereas the rate of an additional diagnosis of alcohol SUD in schizophrenic patients was between 10-70\%. In another study (40), it was reported that alcohol substance use was evident in $52 \%$ of schizophrenic patients, while in a study by Margolese et al. (4I), the substance use rate was $44.9 \%$ in schizophrenic patients; it was $48 \%$ in a study conducted by Wobrock et al. (42). The prevalence of lifelong alcohol use was reported to be $63.3 \%$ in schizophrenic patients in a study conducted in Turkey, while the alcohol abuse/addiction rate was 8. $1 \%$ (34). In the study, only 2 patients had specified the use of marijuana, and I patient who continued to use marijuana was diagnosed with SAD. Alptekin et al. (43) reported an alcohol use disorder rate of $7 \%$ in schizophrenic patients, while Uzun et al. (36) reported the rate of alcohol use and alcohol abuse in schizophrenic patients who received out-patient follow-up care to be $18.1 \%$ and $2.6 \%$, respectively. In our study, only 2 patients were diagnosed with SAD (alprazolam and tianeptine). Belli et al. (38) reported the rates of alcohol use disorder and marijuana use to be $5.9 \%$ and $2.2 \%$, respectively, in their study.

The rates of alcohol SUD in our study are in line with those of Akdavar et al. (34) and Alptekin et al. (43). The lower rate of alcohol and illegal substance use in both the general population and the schizophrenic patients in Turkey than in those in other countries could be the result of religious factors, cultural traditions, and "under reporting," with the latter being a significant limitation of the epidemiological studies conducted in developing countries (44). The high rates of cigarette and alcohol use and the negligible rates of illegal substance use in schizophrenic patients in Turkey compared with those in other countries supports the idea that accessibility and accountability can be important determinants of SUD in psychiatric patients $(40,45)$. Wide availability, easy access, and inexpensiveness of cigarettes and alcohol and the flexibility of the social attitude toward these substances could be facilitating factors in their use. In western countries, the higher prevalence of SUD in schizophrenic patients could be attributed to the accessibility of substances, trend toward non-institutionalized psychiatric treatment, and welfare money provided to unemployed schizophrenic patients. In contrast to western countries, most schizophrenic patients in Turkey live with their family or relatives. Therefore, it could be argued that a controlled living environment and close family relations serve as protective factors against substance use, along with controlled accessibility (46).

In our study, when dividing groups of schizophrenic patients into alcohol 8 substance users and non- users, we did not initially include nicotine use in the substance use category. Similarly, in the study conducted by Verma et al. (47), nicotine was not included among stimulating substances. The exclusion of nicotine can be largely ascribed to its widespread use in the community as well as the common neurobiological mechanisms observed in schizophrenia and nicotine use. In line with the literature, among the schizophrenic patients included in the study, the prevalence of alcohol substance use was significantly higher in males than in females $(5,48,49,50)$.

In terms of marital status, similar to the findings of Westermeyer et al. (5I), we did not find a significant relationship between substance use and marital status in our study. A significant difference, however, was noted between alcohol substance use and marital status in schizophrenic patients in another study conducted in Turkey $(34,52)$. Various studies have indicated a more widespread use of alcohol substances in unmarried individuals than in married ones $(5,42,53)$ as well as a more widespread use of alcohol and substances among married schizophrenic patients ( 31 ). The existence of strong family bonds in Turkish culture and the support that schizophrenic patients receive from their families, regardless of whether they are married, could explain the failure to find a relationship between marital status and alcohol substance use.

Similar to the findings of Altınay et al. (52) on schizophrenic patients, we did not detect a significant difference between alcohol substance users and non-users in terms of their places of birth and residence. This finding, however, is not in line with the literature data, which show higher rates of substance use in patients living in rural areas $(31,54,55)$. The reason for this inconsistency could be the small proportion of patients in the schizophrenia sample group that live in rural areas.

Our study differs from other studies in that it has demonstrated no significant difference between alcohol substance user schizophrenic patients and non-users in terms of duration of education; thus, a lower level of education was not found to be associated with a higher incidence of alcohol substance use $(5,40,42)$. Swartz et al. (53) reported on I 460 schizophrenic patients in their Catie study, indicating that there was no significant difference between alcohol substance users and non-users in terms of the level of education.

In the literature, although there are some studies that suggest no significant relationship between job status and alcohol substance use $(31,47)$, there are several studies demonstrating a significant association between joblessness and alcohol substance use $(35,40,42,47,53)$. In our study, there were a higher number of people who did not have a regular job in the alcohol substance non-user schizophrenic patient group, whereas there were a higher number of retired and regular workers in the alcohol substance user schizophrenic patient group. In studies where the prevalence of alcohol substance user schizophrenic patients with favorable premorbid characteristics was more frequent $(49,56)$, a better social functionality in terms of desire for and intention toward alcohol substance use could take place. In the alcohol substance non-user group, given that compared with the general community, there were a higher number and greater frequency of female patients who were housewives as opposed to those who held a regular job outside, we anticipated a higher rate of unemployment in the alcohol substance user group. In the alcohol substance non-user schizophrenia group, despite a higher percentage of non-workers, the similarity of monthly income suggests the existence of an employed person in the family. This supports the idea that there is no significant difference between the two groups in terms of monthly income because of the higher number of women found in the alcohol substance non-users, a result possibly indicating that unemployed women are readily accepted by society and that the family needs are met by their partner. In our study, patients in 
the alcohol substance user schizophrenia group were mostly retired and regular workers, which indicates they had their own incomes and were able to independently access substances.

In the study conducted by Verdoux et al. (57), the age of disease onset occurred earlier in the alcohol substance user schizophrenia group compared with the non-user group. Furthermore, in agreement with our study, another study conducted in Turkey showed no significant difference between alcohol user schizophrenic patients and non-user patients (52). In the literature, several studies demonstrate non-significant relationships between alcohol substance use and the age of onset of disease symptoms $(31,34,47)$.

No statistically significant difference was found in our study when comparing alcohol substance user and non-user schizophrenia groups in terms of first admission to the doctor, age at first hospital stay, and duration of disease. Some studies in the literature suggest an earlier age at first hospital admission and that at first hospital stay in the alcohol substance user schizophrenia groups $(57,58)$, whereas other studies did not detect a significant relationship between age at first hospital admission and that at first hospital stay and alcohol substance use $(31,52)$. However, when we repeated the analysis after including nicotine use, the age at first hospital stay in the LLNAS schizophrenia group was lower compared with that in the non- LLNAS schizophrenia group. In accordance with the literature, in our study, the duration of total hospital stay was significantly longer in the alcohol substance user schizophrenia group compared with that in the non-user schizophrenia group $(59,60)$.

Alcohol addiction is a known risk factor for suicide in schizophrenia $(61,62)$. However, in agreement with the results by Rosau et al. (63) study, in our study, there were no significant differences between alcohol substance user and non-user groups in terms of suicide attempts and the number of attempts. When we repeated the analysis after including nicotine users in the LLNAS user schizophrenia group, we found that the history of self-harm behavior was more frequently seen in the LLNAS user schizophrenia group than in the LLNAS non-user group.

There was no significant difference between alcohol substance user and non-user schizophrenia groups in terms of family history of psychiatric disorders, and the most frequent psychiatric disorder in both groups was schizophrenia. This situation is in line with the study results showing higher rates of individuals with a hospitalized family member and a family member with a diagnosis of psychiatric illness (26.3\%). Kendler and Gardner (64) had evaluated three family studies from Denmark, Ireland, and the USA and found a higher risk of alcohol addiction in the family members of patients diagnosed with schizophrenia only in the Denmark study. However, when the data was evaluated comprehensively, it was evident that alcohol addiction did not increase in family members.

In our study, we did not detect a significant difference in terms of lifelong nicotine use in alcohol substance user schizophrenia groups and non-user groups. In the alcohol substance non-user group, lifelong nicotine use was $58 \%$, whereas it was $88 \%$ in the alcohol substance user schizophrenia group. Karşıdağ et al. (35) in their study found 3-4 times more frequent alcohol and 5 times more frequent substance use in cigarette smokers compared with non-smokers. These results indicate that the existence of an addictive substance occurs more frequently when another substance is present.

The literature reveals different findings regarding the relationship between alcohol substance use and distribution and severity of psychotic symptoms. Some studies showed more severe delusions and hallucina- tions in patients who in addition to schizophrenia were also diagnosed with alcohol SUD $(31,48,58,65,66)$, while Dixon et al. (56) reported less severe delusions and hallucinations. Talamo et al. (48), after reviewing 9 manuscripts published between 1994 and 2000, found that positive symptom scores were higher and negative symptom scores lower in substance-using schizophrenic patients compared with non-substance users. In the year-long follow-up study on schizophrenic patients, Cuffel and Chase (67) reported significantly higher rates of depressive symptoms in those continuing to use or those who started using substances. In our study, we did not detect a statistically significant difference between the two groups in terms of the UKU-SERS, IRS, BDQ, GAF, SAPS, SANS, and CDS points applied to schizophrenic groups.

The question which arises is that who are alcohol substance users and non-users. In the schizophrenia group with LLASUD, compared with the schizophrenia group without LLASYD, the IGD scale score was found to be lower.

This result is in line with that of Chouljian et al. (68) who reported a worse social functionality due to a more severe cognitive insufficiency and introversion in schizophrenic patients with SUD. A SUD involving alcohol substance use in schizophrenic patients indicates a second additional diagnosis, and this can possibly result in lower functional abilities. It was found that schizophrenic patients with LLNASU received higher scores in the UKUSERS autonomic subscale compared with schizophrenic patients without LLNASU. This result can be explained by the anticholinergic effects of nicotine. There are also studies that do not detect the clinically significant differences between patients diagnosed with schizophrenia and alcohol substance use and those diagnosed with schizophrenia and nonuse $(34,69,70)$.

The limitations of this study include the performance of the study in a tertiary referral center, the reliance on individual declarations in the determination of the prevalence of alcohol substance use, and the cross sectional design of the study. In studies conducted on this topic, different results might be observed due to the use of different terminologies regarding the definition of substance use, addiction, abuse, use, problematic use, and current and lifelong use types of substance use. Considering these methodological differences, we repeated our analyses 3 times after grouping patients into those with and without alcohol SUD; those who use and do not use nicotine, alcohol, and other substances; and those who are alcohol substance users and those who are not. We, however, found very different results in terms of clinical progression. Finally, we believe that this study will contribute to the current literature on the subject, as there is currently a paucity of studies on the prevalence of alcohol substance use in patients diagnosed with schizophrenia in Turkey.

Conflict of Interest: No conflict of interest was declared by the authors.

Financial Disclosure: The authors declared that this study has received no financial support.

\section{REFERENCES}

I. Degenhardt L, Hall W. Alcohol, cannabis and tobacco use among Australians: Acomparison of their associations with other drug use and use disorders, affective and anxiety disorders, and psychosis. Addiction 200 I; 96: I603-16 I4. [CrossRef]

2. Şizofreni ve Eştanılı Durumlar, Tanı ve Tedavi. I.Baskı. Üçok A, çev. Editörü. İstanbul: Yelkovan Yayıncılık; 2002.

3. Bermanzohn PC, Port L, Siris SG. Hierarchical diagnosis in chronic schizophrenia: a clinical study of co-occuring syndromes. Schizophr Bull 2000; 26:519. 527. [CrossRef] 
4. Kessler RC, McGonagle KA, Zhao S. Life time and 12-month prevalence of DSMIII-R psychiatric disorders in the US: Results of the National Comorbidity Survey. Arch Gen Psychiatry 1994; 51:8-19. [CrossRef]

5. Mueser KT, Yarnold PR, Levinson DF, Singh H, Bellack AS, Kee K, MorrisonRL, Yadalam KG. Prevalence of substance abuse in schizophrenia: demographic and clinical correlates. Schizophr Bull 1990; 16:31-56. [CrossRef]

6. Ziedonis DM, Fisher W. Assessment and treatment of comorbid substance abuse in individuals with schizophrenia. Psychiatric Annals 1994; 24:477-483. [CrossRef]

7. Strakowski SM, Tohen M, Stoll AL, Faedda GL, Mayer PV, Kolbrener ML, Goodwin DC. Comorbidity in psychosis at first hospitalization. Am J Psychiatry 1993; 150:752-757. [CrossRef]

8. Regier DA, Farmer ME, Rae DS. Comorbidity of mental disorders with alcohol and other drug abuse: results from the Epidemiologic Catchment Area Study. JAMA 1990; 264:25 I I-25 I8. [CrossRef]

9. Kavanagh DJ, Trembath M, Shockley N, Connolly J, White A, Isailovic A, McDYoung R, Saunders JB, Byrne G], Conno J. The Drug Check Problem List: A new screen for substance use disorders in people with psychosis. Addict Behav 201 I; 36:927-932. [CrossRef]

10. Blanchard J], Brown SA, Horan WP. Substance use disorders In schizophrenia: review, integration and a propose model. Clin Psychol Rev 2000; 20:207-2 I3. [CrossRef]

II. Winokur G, Coryel W, Endicott j, Keller M, Akiskal H, Solomon D. Familial alcholism in manic-depressive (bipolar) disease. Am J Genet Neuro Psychiatr Genet 1996; 67:197-201.

12. McElroy SL, Strakowski SM, Keck PE, West SA. The effects of antecedent substance abuse on the development of first epizod psychotic mania. J Psychiat Res 1996; 30:59-67. [CrossRef]

13. First MB, Spitzer RL, Gibbon M. Structured clinical interview for DSM-IV clinical version (SCID-I/CV). Washington DC, APP, 1997.

14. Çorapçıoğlu A, Aydemir O, Yıldız M. DSM IV Eksen I Bozuklukları (SCID I) icin Yapılandırımış Klinik Görüşme-Klinik Versiyon. Ankara, Hekimler Birliği Yayınevi, 1999.

15. Kaplan İ. Yarı kırsal alanda bir sağık ocağına başvuran hastalarda ruhsal bozuklukların yeti yitimi ile ilişkisi. Türk Psikiyatri Dergisi 1995; 6:169-179.

16. Lingjaerde O, Ahlfors UG, Bech P. The UKU Side Effect Rating Scale. Acta Psychiatr Scand 1987; 76(Suppl 334):I-96.

17. Babor TF, Higgins-Biddle JC, Saunders JB, Monterio MG. AUDIT The Alcohol Use Disorders Identification Test: Guidelines for use in primary care (2nd ed.). WHO/MSD/MSB/0I Ga, Geneva: World Health Organization, 200I.

18. Saatcioğlu Ö, Evren C, Çakmak D. Alkol kullanım bozuklukları tanıma testinin geçerliği ve güvenirliği. Türkiye'de Psikiyatri 2002; 4: 107-I I3.

19. Fagerström $\mathrm{KO}$, Heatherton TF. The fagerstrom test for nicotine dependence: a revision of the fagerstrom tolerance questionnaire. Br J Adicct 200 I; 86: I | 19-1 | 27

20. Uysal MA, Kadakal F, Karşıdağ Ç ve Bayram NG, Uysal Ö, Yılmaz V. Fagerstrom test for nicotine dependence: Reability in a Turkish sapmle and factor analysis. Tuberk Toraks 2004; 52:1 I 5-121.

21. David AS. Insightandpsychosis. Br J Psychiatry 1990; 156:798-808. [CrossRef]

22. Arslan S, Günay Kilıç B, Karakılıç H. İçgörünün Üç Bileşenini Değerlendirme Ölçeği güvenirlik ve geçerlik çalışması. Türkiye'de Psikiyatri 200 I; 3: 17-24.

23. Luborsky L. Clinicians' judgements of mental health. Arch Gen Psychiatry 1962; 7:407-417. [CrossRef]

24. Sorias O. Madde kullanımı ile ilişkili bozukluklar, Psikiyatri Temel Kitabı, I. Baskı, 1997.

25. Anderasen NC. The Scala for the Assesment of Positive Symptoms (SAPS) lowacity, university of lowa, 1984.

26. Erkoç Ş, Arkonaç O, Atakı C, Özmen E. Pozitif ve Negatif Semptomları Değerlendirme Ölçeğinin güvenilirliği ve geçerliliği. Düşünen Adam 199; 4: 16-24. [CrossRef]

27. Anderasen NC. The Scala for the Assesment of Negative Symptoms (SANS) lowacity, university of lowa, 1983

28. Erkoç Ş, Arkonaç O, Ataklı C. Negatif semptomları değerlendirme ölçeğinin (SANS) güvenilirliği ve geçerliliği. Düşünen Adam 199|; 4:I4-19.

29. Addington D, Addington J, Maticka-Tyndale E, Joyce J. Reliability and validity of a depression rating scale for schizophrenics. Schizophr Res 1992; 6:201-208.

30. Aydemir Ö, Danacı AE, Pırıldar ŞA, Deveci A, İçelli İ. Calgary Şizofrenide Depresyon Ölçeğiınin Türkçe versiyonunun duyarlılı̆̆ ve özgüllüğü. Arch Neuropsychiatr 2000; 37:210-213.
31. Aich TK, SinhaVK, Khess CRJ, Singh S. Demographic and clinical correlates of substance abuse comorbidity in schizophrenia. Indian J Psychiatry 2004 46:135-139.

32. Lohr G, Lohr JB, FllynnK. Smoking and schizophrenia. Schizophr Bull 1992; 8:93- 102. [CrossRef]

33. Dixon L, Wohlheiter K, Thompson D. Comprehensive Care of Schizophrenia. A Textbook of Clinical Management. Lieberman JA, Murray RM (eds). Dunitz 200 I.

34. Akvardar Y, Tumuklu M, Akdede BB. Substance use among patients with schizophrenia in a university hospital. Bull Clin Psychopharmacol 2004; 14:191 - 197.

35. Karşıdağ Ç, Alpay N, Kocabıyık A. Şizofreni ve Sigara Bağımlılığı. Düşünen Adam 2005; 18:13-20.

36. Uzun Ö, Cansever A, Basoğlu C, Özşahin A. Smoking and substance abuse in outpatients with schizophrenia: A 2-year follow up study in Turkey. Drug Alcohol Depend 2003; 70:187-192. [CrossRef]

37. Üçok $A$, Polat $A$, Bozkurt $O$, Meteris $H$, Cigarette smoking among patients with schizophrenia and bipolar disorders. Psychiatry Clin Neurosci 2004; 58:434-437. [CrossRef]

38. Belli H, Özçetin A, Ertem Ü. Şizofreni hastalarında bazı sosyodemografik özellikler ve tedavi ile ilişkili etkenler. Anadolu Psikiyatri Dergisi 2007; 8: I02-1 I 2.

39. Akvardar Y, Türkcan A, Yazman Ü. Prevalence of alcoholuse in Istanbul. Psychol Rep 2003; 92: I08 I - 1088. [CrossRef]

40. Mueser KT, Yarnold PR, Rosenberg SD. Substance use disorder in hospitalized mentally ill psychiatric patients: prevalence, correlates, and subgroups. Schizophrenia Bull 2000; 26: 179-192. [CrossRef]

4I. Margolese HC, Malchy L, Negrete JC. Drug and alchol use among patients with schizophrenia and related psychoses: levels and consequences. Schizophr Res 2004; 67:157-166. [CrossRef]

42. Wobrock T, Sittinger H, Behrendt B, D'Amelio R, Falkai P, CaspariD. Comorbid substance abuse and neurocognitive function in recet onset schizophrenia. Eur Arch Psychiatry Clin Neurosci 2007; 257:203-2 10. [CrossRef]

43. Alptekin K, Mete L, Yazıcı K. Comorbid substance abuse and smoking inTurkish patients with schizophrenia. Schizophr Res 2002; 53(Suppl):224.

44. Akkaya C, Altın M, Kora K. Türkiye'de bipolar I bozukluğu hastalarının sosyodemografik ve klinik özellikleri. Klinik Psikofarmakoloji Bülteni 20 I 2; 22:3 I-4 I

45. Cantor-Graae E, Nordstrom LG, McNeil TF. Substance abuse in schizophrenia: are view of literature and a study of correlates in Sweden. Schizophr Res 200I; 48:69-82. [CrossRef]

46. Bağımlıık Ve Komorbidite, Duran çakmak, Ömer Saatçioğlu, İstanbul, Say Yayınevi, 2005

47. Verma SK, Subramaniam M, AnnChong S, Kua EH. Substanceabuse in schizophrenia A Singapore perspective. Soc Psychiatry Psychiatr Epidemiol 2002; 37:326-328. [CrossRef]

48. Talamo A, Centorrino F, Tondo L, Dimitri A, Hennen J, Baldessarini RJ. Comorbid substance-use in schizophrenia: relation to positive and negative symptoms. Schizophr Res 2006; 86:25I-255. [CrossRef]

49. Mueser KT, Bellack AS, Blanchard J]. Comorbidity of schizophrenia and substance abuse: implications for treatment. J Consult Clin Psychol 1992; 60:845856. [CrossRef]

50. Overall J, Gorham D. The brief psychiatric rating scale. Psychol Reports 1962; |0:799-8|2. [CrossRef]

51. Westermeyer J], Schneekloth TD. Course of substance abuse in patients with and without schizophrenia. Am J Addict 1999; 8:55-64. [CrossRef]

52. Altınay CU. Şizofren hastalarda alkol madde kullanım bozukluğu komorbiditesi ve komorbiditenin hastalık gidişine etkileri. Tipta uzmanlık tezi (2005)

53. Swartz M, Miller D, Ryan H, Wagner F. SubstanceUseandPsychosocialFunctioning in SchizophreniaAmong New Enrollees in the NIMH CATIE Study. Psychiatric Services 2006; 57: I | | 0- I | | 6. [CrossRef]

54. Cuffel BJ. Prevalence estimates of substance abuse in schizophrenia and their correlates. J Nerv Ment Dis 1992; 180:589-592. [CrossRef]

55. Soyka M. Alcoholism and schizophrenia. Addiction 2000; 95:1613-1618. [CrossRef]

56. Dixon L, Haas GH, Weiden PJ, Sweeney J, Frances AJ. Drug abuse in schizophreinic patients: clinical correlates and reasons for use. Am J Psychiatry |99|; | 48:224-230.

57. Verdoux H, Mury M, Besançon G, Bourgeois M. Comparative study of substance dependence comorbidity in bipolar, schizophrenic and schizoaffective disorders. Encephale 1996; 22:95-101. 
58. Green A, TohenM, Strakowski. First episode schizophrenia-related psychosis and substance use disorders: acute response to olanzapine and haloperidol Schizophr Res 2004; 66:125-135.

59. Brady K. Anton R. Ballenger J. Cocaine abuse among schizophrenic patients. Am J Psychiatry 1990; 147:9.

60. Dervaux A, Laqueille X, Bourdel MC, Leborgne MH, Olié JP, Lôo H, Krebs MO. Cannabis and schizophrenia: demographic and clinical correlates. Encephale 2003; 29: I 1- 17.

61. Soyka M, Albus M, Kathmann N. Prevalence of alcohol and drug abuse in schizophrenic inpatients. Eur Arch Psychiatry Clin Neurosci 1993; 242:362-372. [CrossRef]

62. Verdoux H, Liraud F, Gonzales B Assens F, Abalan F, van Os J. Suicidality and substance misuse infirst-admitted subjects with psychotic disorder. Acta Psychiatr Scand 1999; 100:389-395. [CrossRef]

63. Rosau CD, Mortensen PB. Risk factors for suicide in patients with schizophrenia: nested case-control study. Br J Psychiatry 1997; 171:355-359. [CrossRef]

64. Kendler KS, Gardner CO. The risk for psychiatric disorders in relatives of schizophrenic and control probands: a comparison of three independent studies. Psychol Med 1997; 27:4 I I-419. [CrossRef]
65. Smith J, Hucker S. Schizophrenia and substanes abuse. Br J Psychiatry 1994; |65:|3-21. [CrossRef]

66. Soyka M, Albus M, Immler B. Psychopathology in dual diagnosis and nonaddicted schizophrenics-are there differences? Eur Arch Psychiatry Clin Neurosci 2001; 251:232-238.

67. Cuffel BJ, Chase P. Remission and relapse of substance use disorder in schizophrenia: Results from a one year prospective study. J Nerv Ment Dis 1994; 182:342-348. [CrossRef]

68. Chouljian TL, Shumway M, Balancio E. Substance use among schizophrenic outpatients: prevalence, course, and relation to functional status. Ann Clin Psychiatry 1995; 7:19-24. [CrossRef]

69. Mueser KT, Drake RE, Wallach MA. Dual diagnosis: a review of etiological theories. Addict Behav 1998; 23:717-734. [CrossRef]

70. Seibyl JP, Satel SL, Anthony D, Southwick SM, Krystal JH, Charney DS. Effects of cocaine on hospital course in schizophrenia. J Nerv Ment Dis 1993; 181:3 137. [CrossRef] 